\title{
MAKNA LAFADZ IDRIB DALAM QS. AN-NISA AYAT 34 PERSPEKTIF ULAMA KABUPATEN MALANG
}

\author{
Muhammad Lukman Haris \\ Fakultas Syari'ah UIN Maulana Malik Ibrahim Malang \\ Email: lukmanmuhammad1@,gmail.com
}

\begin{abstract}
Abstrak
The background of this research, is the fact often indicates that the marital relationship is not always harmonious. Sometimes a spouse fails to save the Big Dipper in the household as it faces problems that are considered to be beyond their means. Sometimes women ignore or less than the maximum husband right in doing his duty to the house and her children. This study aims to describe, how do cleric Malang Meaning Lafadz idrib on Qs. An-Nisa verse 34 and how do Malang cleric on how the settlement of disputes in domestic life which in turn can realize harmonious family. While the object of research is the Ulema Malang. The results of this Penetian, researchers finally, first, the meanings of the Salafi Ulama Lafadz idrib on Qs.AnNisa verse 34 by taking the path of violence that is hitting with the hand, while the scholars of Modern and Contemporary in meaning Lafadz Idrib ie, hit without using street violence, ie by continuously advised.second, Salafi cleric in resolving disputes in domestic life are clubbed, Salaf allow wife beating wives who disobey the reason is still the responsibility of the husband, it is necessary to resort to violence to revive him. Modern and contemporary scholars While there are two methods to resolve disputes that occur in the home, The first is by way of violence, that is allowed to beat his wife as long as the stage-the stage prior to the beating had done well and has not produced results. The second dispute resolution process in the household is, without the use of the least violent way, which is enough to be kept advised menurus due to violence if the problem is not going to finish, and beating only produces more dangerous uprising.

Studinya bertujuan untuk menggambarkan, bagaimana ulama Malang Arti Lafadz idrib pada Qs. An-Nisa ayat 34 dan bagaimana ulama Malang tentang bagaimana penyelesaian sengketa dalam kehidupan rumah tangga yang pada gilirannya dapat mewujudkan keluarga yang harmonis. Sedangkan objek penelitian adalah Ulama Malang. Hasil Penetian ini, peneliti akhirnya, pertama, arti dari Salafi Ulam aLafadzidrib pada Qs.An - Nisa ayat 34 dengan mengambil jalan kekerasan yang memukul dengan tangan, sementara para ulama Modern dan Kontemporer dalam arti Lafadz Idribi adalah memukul tanpa menggunakan jalan kekerasan, yaitu dengan saran atau masukan, kedua, ulama salafi dalam menyelesaikan sengketa kehidupan rumah tangga dengan dipukul, ulama' Salafi membolehkan pemukulan terhadap istri yang tidak taat alasannya adalah karena masih tanggung jawab suami, maka perlu menggunakan kekerasan untuk menghidupkan kembali kepadanya. Sedangkan para ulama' kontemporer pertama adalah dengan cara pendekatan musyawarah, apabila belum membuahkan hasil. Proses penyelesaian sengketa kedua dalam rumah tangga adalah dengan peringatan yang keras, hindari kekerasan karena hanya menghasilkan pemberontakan lebih berbahaya .
\end{abstract}

Kata kunci :Lafadz Idrib, Ulama kabupaten Malang, Qs An-nisa 
Makna Lafdz Idhrib Menurut Para ulama Tafsir.

Masa Salaf

Definisi Salaf (السََّّفن)

Menurut bahasa (etimologi), Salaf ( ( الكسَّلَفْ artinya yang terdahulu (nenek moyang), yang lebih tua dan lebih utama.[1] Salaf berarti

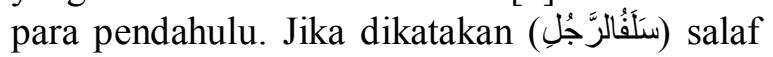
seseorang, maksudnya kedua orang tua yang telah mendahuluinya. ${ }^{1}$

Menurut istilah (terminologi), kata Salaf berarti generasi pertama dan terbaik dari ummat (Islam) ini, yang terdiri dari para Sahabat, Tabi'in, Tabi'ut Tabi'in dan para Imam pembawa petunjuk pada tiga kurun (generasi/masa) pertama yang dimuliakan oleh Allah Subhanahu wa Ta'ala, sebagaimana sabda Rasulullah Shallallahu 'alaihi wa sallam

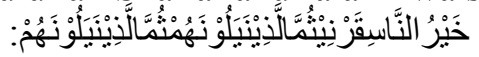

"Sebaik-baik manusia adalah pada masaku ini (yaitu masa para Sahabat), kemudian yang sesudahnya (masa Tabi'in), kemudian yang sesudahnya (masa Tabi'ut Tabi'in.

Penafsiran terhadap Al-Quran pada dasarnya merupakan otoritas Nabi SAW karena hanya nabi- lah yang memahami apa yang dimaksudkan oleh wahyu. ${ }^{2}$ Akan tetapi, karena Nabi SAW tidak menjelaskan seluruh ayat dalam Al-Quran, maka setelah Nabi SAW meninggal, para sahabat memhami Al-Quran dengan cara bertanya pada para sahabat yang ter-kenal sebagai ahli Tafsir. Artinya pada masa sahabat sudah ada penafsiran Al-Quran sekalipun masih bersifat riwayat, yakni belum dikodifikasi atau ditulis dalam sebuah kitab tafsir. $^{3}$

Setelah paruh abad ke-2 Hijriyah, Ulama membukukan Tafsir Al-Quran sebagai bagian dari atau menjadi bab dalam kitab kitab hadis. Cara pembukuan seperti ini berjalan selama satu abad kurang lebih lamanya hingga pada sekitar dasawarsa terakhir abad ke 3Hijriyah atau Dasawarsa pertama pada abad ke4 Hijriyah. Corak penafsirannya masih

\footnotetext{
${ }^{1}$ http://almanhaj.or.id/content/3428/slash/0/definisi-salafdefinisi-ahlus-sunnah-wal-jamaah/. Diakses tanggal 3 Februari 2014 Pukul 16.35.

${ }^{2}$ MF. Zenrif, Sintesis Paradigma Studi Al-Quran, (Malang; UIN Malang Press, 2008), h. 47

${ }^{3}$ Fauzan Zenrif, h. 48
}

berpegang teguh pada cara penafsiran bi al riwayah seperti yang telah dikembangkan sebelumnya ${ }^{4}$. Hanya saja sudah tampak adanya upaya penafsiran Al-Quran dengan menggunakan analisis kebahasaan yang bersifat leksiografis. Yakni pembahasan berdasarkan analisis tata bahasa Arab(I'rab) atau belakangan sering disebut dengan pendekatan atau metode analisis struktural.

Corak tafsir bil al ma'tsur ini masih terus mendominasi model tafsir yang berkembang hingga paruh pertama abad ke-4 Hijriyah. Pada paruh kedua abad ini corak tafsir bil al a'yi mulai bermunculan ke permukaan. Semua corak penafsiran yang berkembang pada masa ini menggunakan metode Tahlily, Yakni penafsiran ayat-ayat Al-Quran sesuai dengan urutan mushaf (Utsmaniy).Metode ini berjalan berabad - abad lamanya. ${ }^{5}$ Diantara para mufassir Kelompok Ini Adalah Imam Athabariy, Imam Al-Syaukaniy, Imam Ibnu Katsir.

Imam Athabariy Dalam Kitab Tafsir At Thabari.

Maknanya dari memukul adalah. "Wahai para suami, nasehatilah istri kalian tentang perbuatan nusyuz mereka. Jika mereka menolak untuk kembali kepada kewajiban mereka, maka ikatlah mereka dengan tali. Dirumah mereka, dan pukullah mereka agar mereka kembali kepada kewajiban mereka, yaitu taat kepada Allah dalam kewajiban mereka terkait dengan hak kalian". Sifat pukulan yang diperbolehkan Allah kepada suami adalah pukulan yang tidak melukai, tidak keras, dan jangan pukulan yang membuat tulangnya patah apalagi pukulan yang sampai membuatnya cacat. ${ }^{6}$

Dr. Abdullah bin Muhammad Bin Abdurahman bin Ishaq Alu Syaikh. Dalam Kitab Tafsir Jalalain.

Makna dari Lafadz Dharab tersebut yaitu jika nasehat dan pemisahan tempat tidur tidak menggetarkannya, maka kalian boleh

\footnotetext{
${ }^{4}$ Fauzan Zenrif, h. 48

${ }^{5}$ Fauzan Zenrif, h. 49

${ }^{6}$ Abu Ja'far Muhammad bin Jarir Ath-Thabari, Jami' Al

Bayan an Ta'wil Ayi Al Quran : "Tafsir Ath-Thabari", diterjemahkan oleh Akhmad Afandi, (Cet. I;

Jakarta:Pustaka Azzam, 2008), 916
} 
memukul nya dengan tidak melukai. ${ }^{7}$ Ibnu Abbas dan Ulama - Ulama Lain berkata : “ Yaitu Pukulan yang tidak melukai. "Al-Hasan al-Basiri berkata "Yaitu Pukulan yang tidak meninggalkan bekas. "para Fuqaha berkata : “ Yaitu tidak melukai anggota badan dan tidak meninggalkan bekas sedikitpun. "Ali bin Abi Talhah mengatakan dari Ibnu Abbas : "Yaitu: Memisahkan dari tempat tidur jika ia terima. Jika tidak Allah mengizinkanmu Untuk memukulnya, dengan pukulan yang tidak menciderai dan yang melukai tulang, jika ia terima. Dan jika tidak Juga, maka Allah menghalalkanmu untuk mendapatkan tebusan darinya. ${ }^{8}$

Fath Qadr

Imam As-Syaukani Dalam Kitab Tafsir

Bahwa sistem yang terdapat dalam AlQuran merupakan hal yang halal bagi si suami untuk memukul istri dengan pukulan yang tidak parah dan pukulan yang tidak melukai pada saat Nusyuz tersebut dikhawatirkan terjadi. ${ }^{9}$ Hal itu diungkapkan bahwa agar si istri benar benar meninggalkan perbuatan Nusyuznya ketika proses pengabaian atau memisahkannya dari tempat tidur tidak mempengaruhinya untuk meninggalkan perbuatan Nusyuznya tersebut. Tetapi jika dengan pengabaian sudah cukup atau istri meninggalkan perbuatan nusyuznya, maka si suami harus menahan diri dari tindakan untuk memukul istri.

\section{Masa Modern}

Pada periode berikutnya, umat Islam semakin majemuk, terutama setelah tersebarnya Islam di luar tanah Arab. Kondisi ini membawa konsekuensi logis terhadap perkembangan ilmu tafsir.Akibatnya, para pakar tafsir ikut mengantisipasinya dengan menyajikan penafsiran ayat al-Qur'an yang sesuai dengan perkembangan zaman dan kehidupan

\footnotetext{
${ }^{7}$ Dr. Abdullah bin Muhammad Bin Abdurahman bin Ishaq Alu Syaikh., " Lubabut Tafsiir Min Ibni Katsiir", diterjemahkan oleh M.Abdul Ghoffar E.M, Tafsir Ibnu Katsir jilid 2 (Cet IV ; Jakarta: Pustaka Imam ASYSYAFI'I,2006) h. 300

${ }^{8}$ Dr. Abdullah, Abdurahman bin Ishaq, h. 300

أي ضربا غير مبرح وظاهر النظم القرآني أنه يجوز للزوج أن يفعل 9 جميع هذه الأمور عند مخافة النشوز للنول
}

umat yang semakin beragam, dari sinilah lahir istilah tafsir modern. ${ }^{10}$

Diantara Mufassir kelompok ini adalah, Tafsir al-Manar Muhammad Rasyid Ridha, Ahmad Musthafa bin Muhammad bin Abdul Mun'im al-Maraghi dalam Tafsir Al Maraghi, Sayyid Qutb.

Sayyid Qutb Dalam Tafsir Fil Zhilalil Quran.

Sejalan dengan maksud dan tujuan semua tindakan di muka maka pemukulan yang dilakukan ini bukanlah untuk menyakiti, menyiksa dan memuaskan diri. Pemukulan ini tidak boleh dilakukan dengan maksud untuk menghinakan dan merendahkan. Juga tidak boleh dilakukan dengan keras dan kasar untuk menundukkannya kepada kehidupan yang tidak disukainya. Pemukulan yang dilakukan haruslah dalam rangka mendidik, yang harus disertai dengan rasa kasih sayang seorang pendidik, sebagaimana yang dilakukan seorang ayah terhadap anak-anaknya dan yang dilakukan oleh guru terhadap muridnya. ${ }^{11}$

Sudah dimaklumi bahwa semua tindakan ini tidak boleh dilakukan kalu kedua belah pihak ini berada dalam kondisi harmonis dalam mengendalikan organisasi rumah tangga yang amat sensitive ini. Tindakan itu hanya boleh dilakukan untuk menghadapi ancaman kerusakan dan keretakan. Karena itu, tindakan itu tidak boleh dilakukan kecuali kalau terjadi penyimpangan yang hanya dapat diselesaikan dengan cara tersebut.

Al-Qurtubi Syaikh Imam. Dalam Tafsir AlQurtubi.

Allah memerintahkan agar memulainya dengan Nasehat dahulu kemudian pisah ranjang, bila belum berhasil maka pukullah, karena itulah yang dapat memperbaikinya dan yang dapat mendorongnya untuk memenuhi hak suaminya. ${ }^{12}$ Sedangkan pukulan disini adalah pukulan pendidikan bukan pukulan yang menyakitkan, tidak mematahkan tulang dan tidak menyebabkan luka seperi meninju

\footnotetext{
${ }^{10}$ Rosihan Anwar, Samudera al-Qur'an, (Bandung: Pustaka Setia, 2001), hlm. 259.

${ }^{11}$ Quthb Sayyid, Tafsir Fizhilalil Qura'an : "Tafsir di Bawah Naungan Qura'an”, diterjemahkan oleh, As'ad Yasin , Abdul Aziz Salam Basyarahil., Muchotob Hamzah (Cet. 4; Jakarta:Pustaka Gema Insani, 2008), h. 359

${ }^{12}$ Imam Al Qurtubi, 401
} 
dan yang semisalnya, karena tujuannya untuk memperbaiki bukan untuk yang lain.

Ahmad Musthafa Al-Maraghi. Dalam Kitab Tafsir Al-Maraghi.

Suami boleh memukul istrinya, asalkan pukulan itu tidak menyakiti atau melukainya, seperti memukul dengan tangan atau tongkat kecil. $^{13}$

Masa Kontemporer.

Perkembangan Tafsir Kontemporer tidak dapat begitu saja dilepaskan dengan perkembangannya di masa modern. Paradigma Tafsir Kontemporer dapat diartikan sebagai sebuah model atau cara pandang, totalitas premis-premis dan metodologis yang dipergunakan dalam penafsiran Al-Quran di era kekinian.

Diantara Mufassir kelompok ini adalah Buku Al-Quran menurut perempuan oleh Aminah Wadud,M. Quraish Sihab. Dalam Tafsir Al Misbah, Prof Dr. Hamka dalam Tafsir Al-Azhar.

Aminah Wadud. Dalam Buku Al-Quran Menurut Perempuan.

Namun tidak bisa diabaikan bahwa pada QS An-Nisa Ayat 34 memang menyebutkan dengan kata dharaba ( memukul). Menurut Lisan Al'arab dan Lane's Lexicon, dharaba tidak mesti menyatakan kekuatan atau kekerasan. Kata ini digunakan dalam Al-Quran, misalnya, dalam ungkapan, "dharaba Allah matsalan.... (Allah memberikan atau menetapakan sebagai contoh....'). Kata ini juga digunakan untuk seseorang pergi, atau 'Mulai mengadakan" perjalanan.

Namun kata ini sangat berbeda dengan bentuk keduanya, bentuk intensif - dharaba : memukul berulang- ulang atau dengan keras. Dipandang dari segi kekerasan yang berlebihan terhadap wanita yang ditunjukkan dalam biografi oleh sahabat dalam kebiasaan yang dikecam oleh Al-Quran (seperti pembunuhan bayi perempuan), maka ayat ini harus diartikan sebagai larangan tindak kekerasan tanpa kendali terhadap wanita. Jadi ini bukan izin,

\footnotetext{
${ }^{13}$ Ahmad Mustofa Al-Maraghi :"Tafsir Al-Maraghi”, diterjemahkan oleh, Bahrun Abu Bakar, Lc, Drs Hery Noer Aly (Cet. 1; Semarang: Cv.Toha Putra, 1986), h. 45
}

melainkan larangan keras terhadap kebiasaan yang ada.

Al-Qura'an tidak pernah meme rintahkan seorang wanita untuk mentaati suaminya. Al-Quran tidak pernah menyatakan bahwa ketaatan kepada suami merupakan ciriciri wanita yang baik', juga bukan prasyarat bagi wanita untuk memasuki komunitas islam, namun demikian dalam perkawinan, bentuk penundukan, wanita benar-benar mematuhi suami mereka, bahwasanya mereka percaya bahwa seorang suami yang secara materi menafkahi keluarganya, termasuk istrinya patut dipatuhi. Bahkan dalam kasus seperti itu, norma pada masa turunnya wahyu, tidak ada korelasi bahwa seorang suami harus memukul istrinya supaya patuh. Interpretasi seperti itu tidak berpeluang untuk berkembang secara universal, dan bertentangan dengan esensi AlQuran dan Sunah Nabi. Interpretasi demikian merupakan kesalahan berat dalam memahami Al-Quran untuk membenarkan kurangnya pengendalian diri sebagai laki-laki.

M. Quraish Sihab. Dalam Tafsir Al Misbah.

Jika seorang wanita nusyuz atau tidak menaati perintah suami, maka untuk menga tasinya, dilakukan 3 hal, pertama memberikan nasihat, jika tidak mendapat respon dari isteri yang nusyuz, dilakukan langkah kedua yaitu menghindari hubungan seks, jika dengan langkah kedua ini isteri tetap nusyuz, dilakukan langkah ketiga yaitu memukulnya, akan tetapi pemukulan ini harus di lakukan dengan tidak meninggalkan bekas atau mencederai fisik seperti tulang yang patah/retak, luka sebab pemukulan tersebut. Bahasa, ketika menggunakan dalam arti memukul, tidak selalu dipahami dalam arti menyakiti atau melakukan suatu tindakan keras dan kasar. Orang yang berjalan kaki atau musafir dinamai oleh bahasa dan oleh Al-Quran yadhribuna fil ardh, Yang secara harfiah berarti memukul bumi.Karena itu perintah diatas dipahami oleh ulama berdasarkan penjelasan Rasulullah, bahwa yang dimaksud dengan memukul adalah memukul yang tidak menyakitkan. ${ }^{14}$

Hamka Dalam Tafsir Al-Azhar

Cara yang Ketiga ini hanya dilakukan kepada perempuan yang memang sudah patut dipukul.

\footnotetext{
${ }^{14}$ M. Quraish Shihab, “Tafsir Al Misbah", (Lentera Hati), h. 410
} 
Atau dalam kondisi yang sudah sangat terpaksa. Laki-laki yang suka memukul istrinya, seakan-akan dipandangnya istrinya itu sebagai budak atau hamba sahaya, padahal istri bukan budak, bukan barang benda, tetapi istri itu manusia dan teman hidup. ${ }^{15}$ Sudah terang bahwa hanya perempuan yang sangat keras kepala yang sampai akan kena pukul, dan hanya laki-laki yang kasar budi yang mempermudah memukul atau lancang tangan. Pendeknya peraturan Tuhan itulah yang baik, Ada keizinan memukul kalau sudah sangat perlu, tetapi orang baik-baik berbudi tinggi, akan berupaya supaya memukul dapat dielakkan. ${ }^{16}$ Jika sangat terpaksa memukul, maka pukullah tetapi jangan yang menyebabkan istri menderita, jangan sampai melukai, jangan sampai membuat istri patah tulang, jangan berkesan, dan jauhi memukul muka karena mukalah kumpulan dari segala kecantikan. Dan hendaklah berpisah pisah pukulan itu jangan hanya disatu tempat, supaya jangan menyakitkan benar.

\section{Metode Penelitian}

Penelitian ini termasuk dalam jenis penelitian Empiris atau Lapangan. Adapun pengertian dari penelitian empiris merupakan penelitian yang pada awalnya adalah data sekunder, untuk kemudian dilanjutkan dengan penelitian tehadap data primer dilapangan, atau terhadap masyarakat 17 Penelitian Hukum empiris juga menggunakan data sekunder sebagai data awalnya, yang kemudian dilanjutkan dengan data primer atau data lapangan. Akibat dari jenis datanya (data sekunder dan data primer), maka alat pengum-pul datanya terdiri dari studi dokumen; pengamatan (observasi), dan wawancara (Interview). ${ }^{18}$

Penulis menggunakan pendekatan penelitian kualitatif. Pendekatan Kualitatif adalah sustu penelitian yang ditujukan untuk mendeskripsikan dan menganalisis fenomena, peristiwa, aktifitas sosial, sikap, kepercayaan, persepsi, pemikiran orang secara individual

\footnotetext{
${ }^{15}$ Prof. Dr. Hamka , "Tafsir Al-Azhar juz 5" (Jakarta: P.T Metro Pos Jakarta, 1981). h.61-62.

${ }^{16}$ Prof.Dr.Hamka, h. 62

${ }^{17}$ Soerjono Soekanto,Pengantar Penelitian Hukum, (Jakarta: UI-Press, 2006), 52

${ }^{18}$ Amiruddin, SH,. M.Hum. H. Zainal Asikin, S.H, Pengantar Metode Penelitian Hukum, (Jakarta; Raja GrafindoPersada), h. 134
}

maupun kelompok. ${ }^{19}$ Beberapa deskripsi digunakan untuk menemukan prinsip-prinsip dan penjelasan yang mengarah kepada penyimpulan. Penelitian kualitatif bersifat in-duktif; peneliti membiarkan permasalahan-permasalahan muncul dari data atau dibiarkan terbuka untuk interpretasi.Data dihimpun dengan pengamatan yang seksama, mencakup deskripsi dalam konteks yang mendetail disertai catatancatatan hasil wawancara yang mendalam, serta hasil analisis dokumen dan catatan-catatan. Lokasi penenelitian yang di-lakukan oleh peneliti di kecamatan Kepanjen, Kabupaten Malang, dan di Kecamatan gondanglegi

Untuk memperoleh data digunakan teknik pengumpulan data sebagai berikut: pertama, Data Primer yaitu data langsung dari sumber utama. Dalam hal ini peneliti menggali sumber dengan melakukan penelitian secara langsung terhadap Ulama Kecamatan Kepanjen dan Kecamatan Gondanglegi Kabupaten Malang. Kedua, Sumber data sekunder yaitu data-data yang dikumpulkan, diolah dan disajikan oleh pihak lain mencakup dokumendokumen resmi, buku-buku, maupun hasil penelitian yang berwujud laporan. ${ }^{20}$ Data yang dimaksud adalah data-data yang diperoleh dari Ulama Kabupaten Malang.

Untuk mendapatkan data yang diperlukan dalam penelitian ini, penulis menggunakan berbagai macam metode dan tek-nik pengumpulan data yang tepat. Tujuannya agar diperoleh data yang obyektif. Adapun teknik pengumpulan data tersebut adalah dengan metode wawancara dan dokumentasi.

Setelah data terkumpul dari hasil pengumpulan data, maka perlu adanya pengolahan dan analisis data, ini dilakukan tergantung pada jenis datanya. Karena metode analisis yang digunakan adalah pendekatan kualitatif maka data yang dianalisa dengan menguraikannya dalam bentuk kalimat yang baik dan benar, sehingga mudah dibaca dan diberi arti (interpretasi). ${ }^{21}$

\footnotetext{
${ }^{19}$ Prof. Dr. Nana Syaodih Sukmadinata, Metode Penelitian Pendidikan, (Bandung; Rosda, 2005), 60

${ }^{20}$ Soerjono Soekanto, Penelitian Hukum Normatif (Jakarta: Raja Grafindo, 2003) ,12

${ }^{21}$ Fak. Syari'ah, Pedoman Penulisan, 30
} 
Dalam analisis data, penulis berusaha untuk memecahkan masalah dengan menganalisis data-data yang berhasil dikumpulkan, selanjutnya dikaji dan dianalisis sehingga memperoleh data yang valid. Kemudian peneliti akan melakukan analisis data guna memperkaya informasi. Analisis data dimulai dengan editing, calssyfiying, verifying, analyzing, dan concluding (kesimpulan).

Makna Lafadz Idrib menurut Ulama Kabupaten Malang.

Apabila istri tetap enggan berhenti dengan nasehat dan menjauhi ranjang, maka ia harus mendidiknya dengan pukulan yang tidak menyakitkan, pukulan yang lembut halus dan mendidik, bukan pukulan yang merusak sehingga setan yang menipunya dengan pembangkangan dan penentangan keluar dari kepalanya.

Tentu cara yang ini hanya dilakukan kepada perempuan yang memang sudah patut dipukul. Ada kaum perempuan terpelajar, yang mengukur seluruh perempuan dengan dirinya sendiri, menyanggah keras dengan kebolehan seperti ini terhadap kaum ibu yang lemah, Dia agaknya tidak sadar bahwa memang ada perempuan yang memang pukul yang hanya dapat memperbaiki kedurhakaannya ${ }^{22}$.

Sebagai Ulama Salaf Desa Ganjaran Kecamatan Gondanglegi KH. Mukhlis Yahya mengatakan:

Menurut pendapat saya Makna Dari lafadz Wadhribuhunna tersebut adalah "Memukul" suami boleh memukul istrinya asalkan jika tahapan-tahapan sebelumnya sudah dilaksanakan dengan baik dan benar, dikarenakan istri sudah sangat keterlaluan dan disisi lain istri masih menjadi tanggung jawab suami. Kerana terdapat orang yang sifatnya kesadarannya tumbuh ketika menggunakan cara kekerasan ${ }^{23}$.

Sebagai Ulama Salaf di Murcoyo Gondang legi Wetan Kecamatan Gondang legi Beliau, KH. Zainul Fanani mengatakan:

\footnotetext{
${ }^{22}$ Prof. Dr. Hamka , "Tafsir Al-Azhar juz 5" (Jakarta: P.T Metro Pos Jakarta, 1981). h.63

${ }^{23}$ Toriq, Wawancara, Malang, Tanggal 05 september 2013
}

Menurut saya Makna dari lafadz idrib tersebut adalah "Memukul" suami diperbolehkan untuk memukul dengan pukulan yang niatnya untuk memberikan pendidikan kepada istri dan dalam memukul tersebut memukul pada anggota tubuh yang tidak membahayakan, guna menyadarkan istrinya tersebut agar taat kembali kepada kewajibannya sebagai mana seorang istri yang telah disyariatkan dalam agama. ${ }^{24}$

Sebagai Ulama Salaf Desa Ketapang Kecamatan Kepanjen Kabupaten Malang, KH. M Suadi Said Mengatakan: Menurut saya makna dari lafadz Idrib tersebut adalah "Memukul", Dikarenakan menurut saya suami boleh memukul istri jika si istri memang benar benar keterlaluan atas perbuatan nusyuznya kepda suaminya, di sisi lain istri masih menjadi tanggung jawab suami .Jadi si suami wajib mendidiknya sekalipun dengan jalan kekerasan. Menurut saya diperbolehkannya suami memukul karena islam mngajarkan ketegasan kepada uamatnya. ${ }^{25}$

Sebagai Ulama Modern serta pendiri sekaligus pengasuh Pondok Pesantren $\mathrm{Pu}$ tra Miftahul Huda Kepanjen Kabupaten Malang KH. Abdul Wahab mengatakan:

Menurut Saya makna dari Lafadz Idrib tersebut adalah Pukulan dengan perkataan bukan pukulan dengan tangan atau dengan cara kekerasan. Pukulan dengan perkataan, yang kiranya perkataan tersebut dapat membuat si istri sadar dan berubah menjadi lebih baik. Dikarenakan perkataan itu bisa menembus segala sesuatu yang keras sekalipun itu batu. ${ }^{26}$

Ulama Modern dan sebagai pengajar di Sma Islam Kecamatan Kepanjen Kabupaten Malang Ust Munir mengatakan :Menurut saya makna dari lafadz Idrib tersebut adalah "Memukul", si suami boleh memukul istri dengan pukulan yang tidak menciderai,

\footnotetext{
${ }^{24}$ Naim, Wawancara, Malang, Tanggal 07 september 2013

${ }^{25}$ Khosim, Wawancara, Malang, Tanggal 10 September 2013.

${ }^{26} J a$ 'far, Wawancara, Malang, Tanggal 13 september 2013.
} 
meninggalkan bekas sedikitpun dan tidak keras sama sekali dan memukulny aharus pada bagian yang kiranya tidak membahayakan istri, alasan di perbolehkannya memukul karena segala pola prilaku istri menjadi tanggung jawab suami. ${ }^{27}$

Sebagai Ulama Modern dan Sebagai pengasuh Pondok Pesantren Puti Tarbiyatul Quran (PPTQ) Kepanjen Malang. Ustdz.Siti Romlah mengatakan:

Menurut saya makna dari Lafadz Idrib tersebut adalah, Suami boleh memukul dengan pukulan yang tidak membahayakan dan pukulan yang niatnya bukan untuk melukai dan mencelakai si istri, dan pukulan tersebut harus dilakukan dengan pelan tanpa mengeluarkan suara sebagaimana layaknya orang memukul, bagian itu adalah mulai pusar sampai kebawah. 28

Sebagai Ulama Kontemporer dan Sebagai Pengasuh Pondok Pesantren Syraif Hidayatullah, Kepanjen Kabuapten Malang. Dan Pengajar Mata Kuliah Ilmu Balaghah di STIT Ibnu Sina Kepanjen.KH. Zainul Arifin mengatakan:

Menurut pendapat saya makna dari lafadz Idrib tersebut adalah Sarana bagi suami untuk menyadarkan istri tanpa ada rasa dendam dan efek jera, walaupun keadaanya darurat tidak diperbolehkan dan dibenarkan untuk memukul, karena memukul akan mengakibatkan dan menumbulkan rasa dendam dan dengan memukul tersebut tidak akan menyelesaikan permaslahan yang se-dang terjadi dalam kehidupan rumah tangga. Disamping memukul itu tidak akan menyelesaikan masalah, memukul hanya akan menimbulkan kecemburuan sosial antara suami istri karena dapat dipastikan terdapat pihak yang merasa menang dan terdapat pihak yang merasa dikalahkan dengan pemukulan tersebut. ${ }^{29}$

Sebagai Ulama Kontemporer dan sebagai tenaga pengajar di STIT Ibnu Sina Kepanjen Kabupaten Malang, Ust Arbain

\footnotetext{
${ }^{27}$ Munir, Wawancara, Malang, Tanggal 15 september2013.

${ }^{28}$ Karnoto, Wawancara, Malang, Tanggal 17 september2013.

${ }^{29}$ Hasan ,Wawancara, Malang, Tanggal 20 september 2013.
}

Nurdin mengatakan:Menurut Saya Makna Dari Lafadz Idrib tersebut adalah Sebuah cara suami untuk menyadarkan si istri tanpa menggunakan cara kekerasan dan tidak menimbulkan rasa sakit hati istri. Maka yang harus dilakukan oleh suami adalah memberi pencerahan dengan ilmu pengetahuan, dan harus saling intropeksi antara pihak suami dan istri agar bisa mengambil jalan tengah untuk menyelesaikan permasalahn yang terjadi yang pada akhirnya menimbulkan dan menuju kedamaian kehidupan berumah tangga tanpa ada pihak yang merasa menang dan kalah diantara suami istri tersebut ${ }^{30}$.

Sebagai Ulama Kontemporer dan Sebagai Pengasuh Pondok Pesantren putri Miftahul Huda Kepanjen Kabupaten Malang dan Sebagai Tenaga Pengajar Mata Kuliah Ulumul Quran di STIT Ibnu Sina Kepanjen Malang. Ustz. Esti Luluin mengatakan:

Menurut saya makna dari lafadz Idrib tersebut adalah cara atau alat yang dipergunakan suami untuk menyadarkan istri tanpa timbul rasa dendam dan efek jera pada akhirnya nanti , Sedarurat atau sebahaya apapun keaadannya suami tidak dibenarkan untuk melakukan perbuatan kekerasan atau memukul, karena memukul hanya akan mengakibatkan dan menumbulkan rasa dendam Maka yang harus dilakukan oleh suami adalah memberi pencerahan dengan ilmu pengetahuan, dan harus saling intropeksi antara pihak suami istri dan saling mengenyampingkan sifat watak keras dan rasa keegoisannya masing masing agar meemukan jalan tengah atau menemukan cara yang terbaik untuk menyelesai per-selisihan dan permasalahan tersebut dengan kondisi pikiran yang dingin dan tanpa menggunakan cara kekerasan sedikitpun ${ }^{31}$.

Solusi yang tepat untuk mengatasi permasalahan dan perselisihan yang terjadi dalam kehidupan keluarga.

Sebagai Ulama Salaf Desa Ganjaran Kecamatan Gondanglegi KH. Mukhlis Yahya mengatakan:Menurut saya

\footnotetext{
${ }^{30}$ Arbain ,Wawancara, Malang, Tanggal 23 september 2013.

${ }^{31}$ Dewi, Wawancara, Malang, Tanggal 24 september 2013.
} 
solusi yang tepat untuk mengatasi perselisihan dalam kehidupan rumah tangga adalah si suami harus benar-benar menjadi contoh yang baik bagi istri maupun anak. Karena secara tidak langsung perbuatan suami yang baik tersebut akan dicontoh oleh istri dan anak anaknya. Jadi kuncinya selesai tidaknya suatu permasalahan dalam keluarga tergantung pada suaminya. ${ }^{32}$

Sebagai Ulama Salaf di Murcoyo Gondanglegi Wetan Kecamatan Gondanglegi Beliau, KH. Zainul Fanani mengatakan: Menurut saya solusi yang tepat untuk mnyelesaikan perselisihan dan permaslahan rumah tangga adalah, suami sebagai kepala keluarga harus benar-benar bisa membawa keluarganya menuju yang lebih baik dengan cara menasehati kepada istrinya dan memberikan contoh yang baik kepada istri, karena perbuatan suami yang bagai manapun akan dicontoh oleh istrinya. Jika suami bisa memberi contoh yang baik maka istri akan menjadi baik juga, dan permasalahan dan perselisihan tersebut tidak akan terjadi kembali. 33

Sebagai Ulama Salaf Desa Ketapang Kecamatan Kepanjen Kabupaten Malang, KH. M Suadi Said Mengatakan: Menurut saya solusi yang tepat untuk mengatasi perselisihan dan permasalahan keluarga adalah suami sebagai kepala keluarga harus bisa menjadi suri tauladan yang baik bagi istrinya, karena segala perbuatan atau tindak laku suami akan ditirukan atau akan dicontoh oleh istri, untuk itu suami benar benar dituntut untuk bisa menjadi contoh yang baik bagi istrinya ${ }^{34}$.

Sebagai Ulama Modern serta pendiri sekaligus pengasuh Pondok Pesantren Putra Miftahul Huda Kepanjen Kabupaten Malang KH. Abdul Wahab mengatakan:

Menurut saya solusi yang tepat untuk mengatasi pemaslahan yang terjadi dalam kehidupan keluarga adalah: pihak

\footnotetext{
${ }^{32}$ Toriq, Wawancara, Malang, Tanggal 05 september 2013.

${ }^{33}$ Naim, Wawancara, Malang, Tanggal 07 september 2013.

${ }^{34}$ Khosim, Wawancara, Malang, Tanggal 10 September 2013.
}

suami istri agar mencari momen yang tepat dan indah untuk selanjutnya diajak bicara membahas apa yang sebenarnya terjadi dalam kehidupan rumah tangga tersebu dengan mendatangkan juru damai dari kedua belah pihak,dengan ini suami istri saling intropeksi diri masing - masing supaya saling menyadari semua kesalahannya masing masing, dan setelah menyadarinya maka perdamaian tersebut akan timbul dengan sendirinya ${ }^{35}$.

Ulama Modern dan sebagai pengajar di Sma Islam Kecamatan Kepanjen Ust Munir mengatakan:Menurut saya solusi yang tepat untuk menyelesaikan perselisihan yang terjadi pada kehidupan rumah tangga adalah agar pihak suami istri saling membicarakan secara terang terangan apa sebenarnya yang sebenarnya terjadi, dikarenakan penyebab terjadinya perselisihan terebut bukan tidak mungkin dari istri saja tapi bisa saja datang dari pihak suami.Dengan dilakukannya hal ini permasalahan tersebut akan terselesaiakan secara sendirinya dan jika ini selalu dilakukan, maka permaslahan serta perse-lisihan yank terjadi dalam keluarga tidak akan terjadi kembali. $^{36}$

Sebagai Ulama Modern dan Sebagai pengasuh Pondok Pesantren Puti Tarbiyatul Quran (PPTQ) Kepanjen Malang. Ustdz.Siti Romlah mengatakan:Menurut saya sulusi yang tepat untuk mengatasi permasalahan yang terjadi dalam keluarga adalah; Permasalahan yang timbul dan sekiranya sudah memasuki puncaknya hendaknya dimusyawarahkan dengan kepala yang benar benar dingin, dengan dibantu dengan mendatangkan juru damai dari kedua belah pihak, agar supaya uneg-uneg yang ada dalam hati suami dan hati istri dapat tersampaikan dengan baik sehingga saling mngetahui keinginan masing masing, dengan ini secara langsung akan menyelesaikan permaslahan tersebut, dan jika hal ini dilakukan secara terus menerus maka

\footnotetext{
${ }^{35} \mathrm{Ja}$ 'far, Wawancara, Malang, Tanggal 13 september 2013.

${ }^{36}$ Munir, Wawancara, Malang, Tanggal 15 september 2013 .
} 
permaslahan tidak akan timbul kembali dalam kehidupan keluarga. ${ }^{37}$

Sebagai Ulama Kontemporer dan Sebagai Pengasuh Pondok Pesantren Syraif Hidayatullah, Kepanjen Dan Pengajar Mata Kuliah Ilmu Balaghah di STIT Ibnu Sina Kepanjen. KH. Zainul Arifin mengatakan: Menurut saya solusi yanng tepat untuk menyelesaikan perselisihan dan permasalahan dalam kehidupan rumah tangga adalah: Suami supaya memberikan pencerhan atau ilmu pengetahuan tentang hak dan kewajiban suami istri dan suami istri tersebut agar bisa saling menerima kekurangan masing masing dan supaya mehilangkan sifat egois nya baik suami maupun istri agar perdamaian itu dapat tercipta tanpa menggunakan proses kekerasan sedikitpun. $^{38}$

Sebagai Ulama Kontemporer dan sebagai tenaga pengajar di STIT Ibnu Sina Kepanjen Kabupaten Malang Ust Arbain Nurdin mengatakan:

Menurut saya solusi yang tepat untuk menyelesaikan permaslahan serta perselisihan dalam keluarga adalah: Dengan Mendatangkan Juru damai dari kedua belah pihak, pihak suami dan istri, agar pihak suami istri tersebut bisa saling menerima kekurangan dan kelebihan dari pasangannya, dikarenakan jika saling menerima dan saling mngertia antara suami dan istri permaslahan yang terjadi akan luluh dan akan segera terselesaiakan dengan sendirinya, karena pemicu terjadinya permasalahan tersebut ada-lah pasangan suami istri itu sendiri. ${ }^{39}$

Sebagai Ulama Kontemporer dan Sebagai Pengasuh Pondok Pesantren putri Miftahul Huda Kepanjen Kabupaten Malang dan Sebagai Tenaga Pengajar Mata Kuliah Ulumul Quran di STIT Ibnu Sina Kepanjen Malang. Ustz. Esti Luluin mengatakan:

Menurut saya solusi nya adalah Agar Mendatangkan Juru damai dari kedua

\footnotetext{
${ }^{37}$ Karnoto, Wawancara, Malang, Tanggal 17 september2013.

${ }^{38}$ Hasan ,Wawancara, Malang, Tanggal 20 september 2013.

${ }^{39}$ Arbain ,Wawancara, Malang, Tanggal 23 september 2013.
}

belah pihak, dan nantinya pihak suami maupun istri supaya saling intropeksi dirinya masing-masing, dan tidak hanya bisa saling menyalahkan antara satu dengan yang lainnya, dikarenakan permasalahan yang sedang mendera dalam keluarga tersebut adalah pasangan suami istri itu sendiri. ${ }^{40}$

Makna Lafadz Idrib Pada Qs An-Nisa ayat 34 Menurut Ulama Kabupaten Malang. Ulama Salaf.

KH. Mukhlis Yahya sebagai ulama Salaf mengatakan boleh memukul dengan pukulan fisik, dikarenakan alasan mereka jika sudah memasuki tahap yang terakhir yaitu tahap pemukulan kondisi si istri me-mang tingkat kedurhakaannya terhadap suami sudah keterlaluan dan alasan yang lain, si istri tersebut masih menjadi tanggung jawab suami, maka menurut mereka cara yang am-puh dan mujarab untuk mengobati tersebut adalah dengan cara dipukul. Tetapi pukulan ini diniatkan hanya untuk mendidik si istri, bukan pukulan yang bersifat balas dendam atau yang lainnya, dan bukan pukulan yang keras yang sampai membuatnya luka dan membuatnya cacat. .

Pendapat KH. Mukhlis Yahya sebagai ulama salaf ini senada dengan pendapat Ulama Tafsir Klasik Yaitu Imam AthThabari yang berbunyi :, "Wahai para suami, nasehatilah istri kalian tentang perbuatan nusyuz mereka. Jika mereka menolak untuk kembali kepada kewajiban mereka, maka ikatlah mereka dengan tali.Dirumah mereka, dan pukullah mereka agar mereka kembali kepada kewajiban mereka, yaitu taat kepada Allah dalam kewajiban mereka terkait dengan hak kalian".Sifat pukulan yang diperbolehkan Allah kepada suami adalah pukulan yang tidak melukai, tidak keras, dan jangan pukulan yang membuat tulangnya patah apalagi pukulan yang sampai membuatnya cacat. $^{41}$

\footnotetext{
${ }^{40}$ Dewi ,Wawancara, Malang, Tanggal 24 september 2013.

${ }^{41}$ Abu Ja'far Muhammad bin Jarir Ath-Thabari, Jami' Al Bayan an Ta'wil Ayi Al Quran : "Tafsir Ath-Thabari", diterjemahkan oleh Akhmad Afandi, (Cet. I; Jakarta:Pustaka Azzam, 2008), 916
} 
Sedangkan pendapat KH. Zainul Fanani sebagai ulama' Salaf dalam memaknai lafadz Idrib ini beliau mengatakan boleh memukul dengan tangan dan pukulan tersebut harus diniatkan hanya untuk membri pendidikan kepada istri, agar si istri akan jera dengan segala kedurhakannya terhadap suami. Hal senada juga dikatakan oleh ulama Tafsir salaf yaitu Imam As-Syaukani dalam Tafsir Al-Qadr yang berbunyi :Bahwa sistem yang terdapat dalam Al-Quran merupakan hal yang halal bagi si suami untuk memukul istri dengan pukulan yang tidak parah dan pukulan yang tidak melukai pada saat Nusyuz tersebut dikhawatirkan terjadi. ${ }^{42}$ Hal itu diungkapkan bahwa agar si istri benar benar meninggalkan perbuatan Nusyuznya ketika proses pengabaian atau memisahkannya dari tempat tidur tidak mempengaruhinya untuk meninggalkan perbuatan Nusyuznya tersebut.

KH. M Suadi Said Sebagai ulama Salaf berpendapat $\mathrm{n}$ bahwa makna dari Lafdz Idrib itu adalah Memukul. Menurut beliau si suami diperbolehkan memukul dengan tangan agar si istri kembali taat kepada suami dan kembali melaksanakan segala kewajibannya terhadap suami. Alasan diperbolehkannya memukul karena suami masih mempunyai pertanggung jawaban penuh terhadap istrinya. Pendapat KH. M Suadi Saidtersebut senada dengan pendapat ulama tafsir Salaf yaitu Dr. Abdullah bin Muhammad bin Abdurrahman bin Ishaq Alu Syaikh dalam kitab Tafsir jalalain. Yang berbunyi :Makna dari Lafadz Dharab tersebut yaitu jika nasehat dan pemisahan tempat tidur tidak mengge-tarkannya, maka kalian boleh memukul nya . ${ }^{43}$

Ulama Modern.

KH. Abdul Wahabdalam memaknai lafadz idrib yang ada pada Qs An-nisa ayat 34 sudahlah sangat modern yaitu beliau Mengatakan bahwa itu merupakan perintah memukul, yaitu memukul dengan perkataan

\footnotetext{
أي ضربا غير مبرح وظاهر النظم القرآني أنه يجوز للزوج أن يفعل 42 جميع هذه الأمور عند مخافة النشوز

${ }^{43}$ Dr. Abdullah bin Muhammad Bin Abdurahman bin Ishaq Alu Syaikh., " Lubabut Tafsiir Min Ibni Katsiir”, diterjemahkan oleh M.Abdul Ghoffar E.M, Tafsir Ibnu Katsir jilid 2 (Cet IV ; Jakarta: Pustaka Imam ASYSYAFI'I,2006) h. 300
}

bukan dengan tangan atau dengan cara kekerasan, pukulan dengan perkataan yang kiranya perkataan tersebut dapat membuat istri berubah atau istri kembali taat kepada suaminya. Karena perkataan dapat menembus segala sesuatu yang tidak dapat ditembus oleh batu sekalipun.

Pendapat dari KH. Abdul Wahab tersebut sama dengan pendapat dari Ulama Tafsir Modern Yaiitu Ahmad Mustofa AlMarghi beliau mengatakan bahwa Allah mengingatkan para hambaNya akan kekuasaannya-Nya atas mereka, agar mereka takut kepada-Nya didalam memperlakukan kaum wanita. Sekan-akan Dia berfirman kepada mereka, sesungguhnya kekuasan-Nya atas kalian melebihi kekuasaan kalian atas istri; maka jika kalian berbuat aniaya terhadap mereka, Dia akan menyiksa kalian; dan jika kalian memaafkan kesalahan - kesalahan mereka, niscaya dia akan memaafkan kesalahan kesalahan kalian. ${ }^{44}$

Tidak diragukan lagi, lelaki yang memperbudak wanita akan melahirkan budak bagi orang lain, karena mereka terdidik dengan kzhaliman dan tidak mempunyai kehormatan, sifat-sifat baik dan belas kasihan. Juga akan melahirkan budak wanita dan juga akan melhirkan orang-orang seperti dia; terdidik sebagai budak yang hina dan tidak mempunyai kemulyaan. Sungguh tak ubahnya mereka seperti sekumpulan seorang kambing, dihalau setiap pengembala dan menyambut setiap teriakan. ${ }^{45}$

Ust. Munir mengungkapkan pendapatnya tentang makna lafadz idrib pada Qs An-Nisa Ayat 34, yaitu makna dari lafadz Idrib yang terdapat dalam Qs-An-Nisa ayat 34 tersebut adalah "Memukul", menurut Ust munir suami diperbolehkan untuk memukul istri asalkan sifat dari pukulannya tersebut yaitu dengan pukulan yang tidak menciderai, meninggalkan bekas sedikitpun dan tidak keras sama sekali dan memukulnya tersebut harus pada bagian yang kiranya tidak mem-

\footnotetext{
${ }^{44}$ Ahmad Mustofa Al-Maraghi :"Tafsir Al-Maraghi”, diterjemahkan oleh, Bahrun Abu Bakar, Lc, Drs Hery Noer Aly (Cet. 1; Semarang: Cv.Toha Putra, 1986), h. 48.

${ }^{45}$ Musthafa, Marghi. h. 48
} 
bahayakan istri, menurut beliau bagian yang tidak membahayakan tersebut adalah bagian pusar kebawah, alasan di perbolehkannya memukul karena segala pola perilaku istri menjadi tanggung jawab suami.

Hal senada juga di ungkapkan oleh ulama Tafsir Modern Yaitu Sayyid Qutub, beliau mngatakan bahwa, Sejalan dengan maksud dan tujuan semua tindakan di muka maka pemukulan yang dilakukan ini bukanlah untuk menyakiti, menyiksa dan memuaskan diri. Sudah dimaklumi bahwa semua tindakan ini tidak boleh dilakukan kalau kedua belah pihak ini berada dalam kondisi harmonis dalam mengendalikan organisasi rumah tangga yang amat sensitive ini.Tindakan itu hanya boleh dilakukan untuk menghadapi ancaman kerusakan dan keretakan. Karena itu, tindakan itu tidak boleh dilakukan kecuali kalau terjadi penyimpangan yang hanya dapat diselesaikan dengan cara tersebut. ${ }^{46}$

Kesimpulan pendapat dari Ust Munir memaknai lafadz idrib adalah suami diperbolehkan memukul istri, tetapi hanya dengan niatan untuk mendidik, bukan dengan niatan yang lainnya, seperti niatan merendahkan atau melecehkan. Dan tindakan pemukulan ini hanya boleh dilakukan untuk menghadapi adanya ancaman atau adanya tanda-tanda akan terjadinya keretakan dalam rumah tangga, dan tindakan pemukulan ini boleh dilakukan jika tindakan dari penyimpangan istri terhadap suaminya bisa diselesaikan hanya dengan jalan memukul.

Ustdz. Siti Romlah memaparkan pendapatnya dalam memaknai makna lafadz Idrib yaitu menurut beliau adalah, Suami diperbolehkan untuk memukul istri asalkan sifat dari pukulan tersebut yaitu pukulan yang tidak membahayakan dan pukulan yang niatnya bukan untuk melukai dan mencelakai si istri, dan pukulan tersebut harus dilakukan dengan pelan tanpa mengeluarkan suara sebagaimana layaknya orang memukul, dan bagian yang diperbolehkan untuk dipukul

\footnotetext{
${ }^{46}$ Quthb Sayyid, Tafsir Fizhilalil Qura'an : "Tafsir di Bawah Naungan Qura'an”, diterjemahkan oleh, As'ad Yasin, Abdul Aziz Salam Basyarahil., Muchotob Hamzah (Cet. 4; Jakarta:Pustaka Gema Insani, 2008), h. 359
}

menurut beliau adalah mulai pusar sampai kebawah.

Ustdz.Siti Romlah memberikan alasan atas diperbolehkannya memukul tersebut dikarenakan kondisinya sudah darurat dan sudah kepepet. Dan alasan yang lainnya diperbolehkannya memukul adalah dikarenakan menurut Siti Romlah memang ada sifat dari beberapa manusia di muka bumi ini jika mereka melakukan kesalahan baru sadar atau baru sembuh dari kesalahannya dengan cara kekerasan atau dengan cara dipukul dengan tangan.

Pendapat sama juga dipaparkan oleh ulama Tafsirr Modern Yaitu Sayyid Qutb Dalam kitab tafsir fi zahlil Quran , Yang berbunyi: Memang adakalanya terdapat orang-orang wanita yang tidak mau menjadikan laki-laki yang dicintainya itu sebagai pemimpin dan direlakannya menjadi suaminya kecuali jika lelaki itu dapat menguasai dirinya secara fisik. Meskipun ini tidak menjadi tabiat semua wanita, namun wanita yang demikian itu memang ada. Wanita dengan model demikian inilah yang memerlukan pemecahan tahap akhir ini, supaya dia dapat kembali lurus dan menjaga keutuhan organisasi rumah tangganya dalam kedamaian dan ketrentaman. ${ }^{47}$

Kesimpulan pendapat dari Ustdz Siti Romlah tentang makna Lafadz idrib adalah. Suami boleh memukul istri, jika sudah kepepet, dan asalkan dalm pemukulannya tersebut bukan dengan niatan mencelakai atau dengan niatan merendahkannya, dan jika si istri akan benar-benar sadar setelah dilakukannya tahapan pemukulan ini. Dikarenakan terdapat beberapa wanita yang baru sadar dari semua kesalahankesalahan yang telah dilakukannya itu jika telah dipukul atau dengan cara suami bisa mengendalikan nya dengan cara fisik atau cara kekerasan.

Ulama Kontemporer

KH.Zainul Arifin memaparkan pendapatnya tentang makna Lafadz Idrib pada Qs An-Nisa Ayat 34 . Menurut beliau makna dari lafadz Idrib tersebut adalah Merupakan sarana bagi

\footnotetext{
${ }^{47}$ Quthb Sayyid, h. 359
} 
pihak suami untuk menyadarkan istri yang sedang durhaka atau sedang tidak melaksanakan segala kewajibannya terhadap suami tanpa ada rasa dendam dan efek jera, walaupun dan bagaimanapun keadaanya tidak diperbolehkan dan dibenarkan untuk melakukan pemukulan terhadap istri , karena dengan memukul akan mengakibatkan dan menumbulkan rasa dendam dan dengan memukul tersebut tidak akan menyelesaikan permaslahan yang sedang terjadi dalam kehidupan rumah tangga. Disamping memukul itu tidak akan mnyelesaikan masalah, memukul hanya akan menimbulkan kecemburuan sosial antara suami istri karena dapat dipastikan terdapat pihak yang merasa menang dan terdapat pihak yang merasa dikalahkan dengan pemukulan tersebut.

Pendapat senada juga di uraikan oleh Ulama Tafsir Kontemporer Yaitu Quraish Shihab dalam Tafsir Al-Misbahnya. Menurut Beliau Kata Wadribuhunna yang diterjemahkan dengan pukullah mereka terambil dari kata Dharaba. Yang mempunyai banyak arti. Bahasa dalam menggunakan arti memukul tidak selalu dipahami da-lam arti menyakiti atau melakukan suatu tindakan keras dan kasar. Orang yang berjalan kaki atau musafir dinamai oleh bahasa dan Oleh Al-Quran Yadhribuhunna fil ardh, yaitu secara harfiah berarti memukul bumi. Karena itu perintah diatas dipahami oleh ulama berdasarkan penjelasan Rasulullah SAW, bahwa yang dimaksud dengan memukul adalah pukulan yang tidak menyakitkan.

Kesimpulan dari pendapat $\mathrm{KH}$. Zainul Arifin adalah, dalam makana lafadz idrib ini bukan perintah pihak suami untuk memukul istri, tetapi itu merupakan sarana atau alat yang dipergunakan suami untuk menyadarkan pihak istri yang sedang durhaka, tanpa menimbulkan efek jera dan tanpa menimbulkan rasa dendam dikemudian harinya setelah dilakukannya proses tersebut. Jadi menurut pendapat dari KH. Zainul Arifin Walapun dan bagai- manapun serta serumit apapun kondisinya tetap tidah diperbolehkan untuk melakukan pemukulan terhadap istri.

Ust Arbain Nurdin dalam memaparkan pendapatnya nya tentang makna lafadz idrib pada Qs An-nisa ayat 34 beliau memaknai Lafadz tersebut dengan Sebuah cara suami untuk menyadarkan si istri tanpa menggunakan cara kekerasan dan tidak menimbulkan rasa sakit hati istri. Maka yang harus dilakukan oleh suami adalah memberi pencerahan dengan ilmu pengetahuan, dan harus saling intropeksi antara pihak suami dan istri agar bisa mengambil jalan tengah untuk menyelesaikan permasalahn yang terjadi yang pada akhirnya menim-bulkan dan menuju kedamaian kehi-dupan berumah tangga tanpa ada pihak yang merasa menang dan kalah diantara suami istri tersebut .

Pendapat senada juga dipaparkan oleh ulama Tafsir kontem-porer yaitu Buya Hamka dalam kitab Tafsirnya yaitu Tafsir Al-Azhar : Beliau mengemukakan pendapatnya bahwa, perempuan yang taat bukanlah semata mata perempuan yang tunduk kepada Tuannya. Taat, adalah pe-rempuan yang tahu akan hak dan kewajibannya, yang menjaga rumah tangga dengan baik dan tahu akan tenggang menenggang dan juga tahu akan harha dirinya. Kepada istri yang sudah semacam itu keadaannya, janganlah mencari-cari masalah. Berlakulah hormat-menghormati dalam kehidupan berumah tangga. Karena kalu istri sudah sedemikian rupa baiknya, lalu laki-laki mencari fasal membuat gaduh, jangan disesalkan kalu si istri melawan.Janganlah suatu masalah yang terjadi pada rumah tangga hanya ditimpahkan saja kepada is$\operatorname{tri}^{48}$.Karena meskipun dia perempuan, dia juga manusia yang patut dihormati. Keadaan laki-laki pun sangat cangung kalu wanita itu tidak ada.

\footnotetext{
${ }^{48}$ Prof. Dr. Hamka , "Tafsir Al-Azhar juz 5" (Jakarta: P.T Metro Pos Jakarta, 1981). h.65
} 
Kesimpulan dari pendapat Ust Arbain Nurdin tentang, Makna Lafadz idrib yang ada pada Qs An-Nisa ayat 34 ini adalah : Adalah merupakan cara bagi suami untuk menyelesaikan permasalahan dalam keluarga tanpa menggunakan cara kekerasan sedikitpun, dan tanpa meninggalkan efek sakit fisik maupun sakit hati. Dengan cara saling intropeksi diri antara pihak suami istri dengan apa segala kekurangannya, dan jika ada permasalahan yang terjadi dalam kehidupan rumah tangaa harus diselesaikan bersama-sama tanpa menyalahkan salah satu pihak. Agar permaslahan dapat terselesaikan dengan baik.

Ustdz Ustz. Esti Luluin Memaknai Lafadz Idrib Pada QS anNisa dengan : Cara atau alat yang dipergunakan suami untuk menyadarkan istri tanpa timbul rasa dendam dan efek jera pada akhirnya nanti, Sedarurat atau sebahaya apapun keaadannya suami tidak dibenarkan untuk melakukan perbuatan kekerasan atau memukul, karena memukul hanya akan mengakibatkan dan menumbulkan rasa dendam, yang harus dilakukan yaitu saling intropeksi antara pihak suami istri dan saling mengenyampingkan sifat watak keras dan rasa keegoisannya masing masing agar menemukan jalan tengah atau menemukan cara yang terbaik untuk menyelesai perselisihan dan permasalahan tersebut dengan kondisi pikiran yang dingin dan tanpa meng-gunakan cara kekerasan sedikitpun.

Pendapat yang sama juga diungkapkan Oleh Aminah Wadud. Beliau mengatakan bahwa Jika dipandang dari segi kekerasan yang berlebihan terhadap wanita yang ditunjukkan dalam biografi para sahabat dan oleh kebiasaan yang dikecam dalam AlQuran (seperti pembunuhan bayi perempuan) maka ayat ini harus diartikan sebagai larangan tindak kekerasan tanpa kendali terhadap wanita . Jadi, ini bukan izin melainkan larangan keras terhadap kebiasaan yang ada.
Masalah kekerasan rumah tangga dikalangan muslim dewasa ini tidak bersumber dari ayat Al-Quran ini. Sebagian laki-laki memukul istri mereka setelah benar-benar mengikuti Anjuran Al-Quran untuk mengembalikan keharmonisan rumah tangga. Tujuan laki-laki seperti itu adalah kehancuran bukan keharmonisan. Tindakan demikian mereka lakukan setelah menemukan fakta bahwa mereka tidak dapat merujuk ke ayat 3;34 untuk membenarkan tindakan mereka.

Akhirnya kata Ta'aat dalam ayat ini perlu direnungkan secara kontekstual. Ayat ini berbunyi, "jika mereka ta'aat (tha'aat) kepadamu, jangan kamu mencari jalan untuk menyusahkannya. 'Bagi wantia ini merupakan hukuman bersyarat, bukan suatu perintah.

Al-Quran tidak pernah memerintahkan seorang wanita supaya mentaati suaminya. Al-Quran tidak pernah menyatakan bahwa ketaatan kepada suami merupakan ciri ciri wanita yang baik. Seperti dalam Firman Allah SWT dalam QS At-Tahrim Ayat 5 yang Artinya :

“ jika Nabi menceraikan kamu, boleh Jadi Tuhannya akan memberi ganti kepadanya dengan isteri yang lbih baik daripada kamu, yang patuh, yang beriman, yang taat, yang bertaubat, yang mengerjakan ibadat, yang bepuasa, yang janda dan yang perawan."

Namun demikian, dalam perkawinan bentuk penundukan wanita, wanita benar-benar mematuhi suami mereka, biasanya karena mereka percaya bahwa seorang suami yang se-cara materi menafkahi keluarganya, termasuk istrinya, patut dipatuhi. Bahkan dalam kasus seperti itu, norma pada masa turunnya Wahyu, tidak ada korelasi bahwa jika seorang suami harus memukul istrinya supaya patuh. Interpretasi seperti itu tidak berpeluang untuk berkembang secara universal dan bertentangan dengan esesnsi Al-Quran 
dan Sunnah Nabi.Interpretasi demikian merupakan kesalahan berat dalam memahami Al-Quran untuk membenarkan kurangnya pengendalian diri sebagian laki-laki.

Mengeenai hubungan antara nafkah dan kepatuhan, dapat diamati bahwa ternyata suami yang tidak mau dan tidak mampu memberikan nafkah kepada istrinya pun, meyakini bahwa mereka harus dipatuhi. Sesungguhnya karakteristik dan perkawinan muslim yang tersebar luas ini hanyalah satu contoh dari asosiasi laki-laki sebagai pemimpin alami yang patut dipatuhi.

Kepercayaan terhadap keharusan mematuhi suami ini adalah peninggalan dari perkawinan bentuk penundukan, dan kepercayaan ini tidak hanya terjadi dalam sejarah muslim. Kepercayaan ini belum bertambah baik, walaupun dewasa ini laki-laki dan wanita mencari partner untuk saling memperbaiki emosi, intelektual, ekonomi, dan sepiritual. Kecocokan mereka didasarkan kepada saling menghormati, bukan pada kepatuhan wanita kepada lakilaki. Keluarga dipandang sebagai unit dukungan bersama dan unit kesopanan sosial, bukan institusi untuk menjadikan wanita sebagai budak bagi laki-laki yang membelinya dengan harga tinggi dan kemudian menjamin kebutuhan materi dan fisiknya saja, tanpa memperhatikan aspek pengembangan manusia yang lebih tinggi.

Jika Al-Quran hanya relevan dengan satu jenis perkawinan ini saja, ia akan gagal menghadirkan model yang pas untuk memenuhi berbagai tuntutan dan keperluan yang berubah dari peradaban yang sedang berkebang diseluruh dunia. Karena itu, Nash Alquran memfokuskan pada norma perkawinan di masa turunnya wahyu, dan menerapkan berbagai larangan atas tidakan tertentu suami terhadap istrinya. Dalam konteks yang lebih luas, AlQuran mengembangkan satu mekanime untuk memecahkan permasalahan melalui musyawarah dan arbitrase.
Kesimpulan dari pendapat Ustdz.Ustz. Esti Luluin pendapatnya ten-tang makna lafadz idrib pada Qs An-Nisa Ayat 34 adalah Dalam menyelesaikan rumah tangga tidak boleh dengan melalui jalan kekerasan, karena jalan kekerasan tidak akan menyelesaikan permasalahan yang sedang terjadi dalam kehidupan rumah tangga, dalam hal ini suami istri harus saling intropeksi diri dan mengenyampaikan sifat atau watak keras masing-masing agar menemukan jalan tengah yang disepakati bersama antara suami istri, dengan ini permaslahan tersebut akan terselesaikan dengan sendirinya.

Solusi Mengatasi permaslahan dalam keluarga jika sedang terjadi dalam rumah tangga menurut ulama kabupaten Malang.

\section{Ulama Salaf}

Dalam memberikan pendapat tentang solusi menyenyelesaikan masalah dalam keluarga, KH. Mukhlis Yahya mempunyai pemikiran yang sangatlah modern beliau berpendapat bahwa, si sumai sebagai kepala keluarga harus bisa menjadi contoh yang baik bagi istrinya, dikarenakan secara tidak langsung segala bentuk dari perbuatan si suami tersebut akan ditirukan atau diikuti oleh sang istri, dengan begini si suami benar-benar di tuntut untuk bisa menjadi tauladan yang baik bagi istrinya.

Pendapat yang sama juga dipaparkan oleh ulama Tafsir Kontemporer yaitu $M$ Quraish Shihab dalam tafsir Al Misbah, beliau menjelaskan bahwa, kepemimpinan yang dianugerahkan Allah kepada suami tidak boleh mengantarkannya kepada kesewenang-wenangan. ${ }^{49}$

Keberhasilan perkawinan tidak akan tercapai kecuali jika kedua belah pihak memperhatikan hak pihak lain. Tentu saja hal tersebut banyak, antara

\footnotetext{
${ }^{49}$ M. Quraish Shihab, “Tafsir Al Misbah", (Lentera Hati), h. 408
} 
lain adalah bahwa suami bagaikan pemerintah atau pengembala, dan dalam kedudukannya seperti itu, ia berkewajiban untuk memperhatikan hak dan kepentingan rakyatnya (istrinya). Istri pun berkewajiban untuk mendengar dan mengikutinya. Tetapi disisi lain, perempuan mempunyai hak terhadap suaminya untuk mencari yang terbaik ketika melakukan diskusi.

Dapat disimpulkan bahwa dalam menyelesaikan perselisihan dan permasalahan dalam keluarga tersebut tidak boleh dengan jalan kekerasan sedikitpun kecuali dalam kondisi sangat terpaksa. Pendapat ini senada dengan pentapat ulama Tafsir Kontemporer yaitu Buya Hamka dalam Tafsir AlAzhar yaitu : Seorang suami Supaya bersabar menanggungkan perangaiperangai istrinya. Sebab tiap-tiap perempuan tiap-tiap manusia ada saja kelemahannya. Bahkan engkau sebagai laki-lakipun mempunyai segi kelemahan, yang kesabaran istrimulah yang akan mengekalkan rumah tangga. ${ }^{50}$

Dengan pendapat ini dapat disumpulkan bahwa jika si suami berbuat baik yaitu yang berupa ke-sabaran kepada istrinya maka si istri akan ikut pula sabar kepada suminya dan kesabaran si istri tersebut akan membuahkan hasil yaitu rumah tangga yang kekal dan tidak akan terjadi kembali perselisihan tersebut.

Dalam memberikan pendapat tentang solusi menyenyelesaikan masalah dalam keluarga, KH. Zainul Fanani sangatlah modern dalam pemikirannya, beliau mengatakan bahwa solusi yang tepat untuk menyelesaikan perselisihan dan permasalahan dalam kehidupan rumah tangga adalah: Suami supaya memberikan pencerahan atau ilmu pengetahuan tentang hak dan kewajiban suami istri dan suami istri tersebut agar bisa saling menerima kekurangan masing masing dan supaya mehilangkan

\footnotetext{
${ }^{50}$ Prof. Dr. Hamka , "Tafsir Al-Azhar juz 5" (Jakarta: P.T
} Metro Pos Jakarta, 1981). h.64 sifat egois nya baik suami maupun istri agar perdamaian itu dapat tercipta tanpa menggunakan proses kekerasan sedikitpun.

Pendapat yang sama juga di paparkan oleh Ulama Tafsir Modern Yaitu Imam Al-Qurtubi dalam Tafsir Al-Qurtubi, beliau menjelaskan bahwa Dapat dikatakan bahwa laki-laki memiliki kelebihan potensi jiwa dan tabiat yang kuat yang tidak terdapat pada wanita. Hal itu dikarenakan tabiat lakilaki yang mempunyai semangat menggelora dan keras sehingga dalam dirinya terdapat kekuatan dan kete-guhan. ${ }^{51}$

Kesimpulan dari pendapat $\mathrm{KH}$. Zainul Fanani dalam menyelesaikan per-masalahan yang terjadi dalam rumah tangga adalah, Jika terjadi perselisihan dalam kehidupan berumah tangga. Suami sebagai kepala keluarga supaya memberikan pencerahan atau ilmu pengetahuan tentang hak dan kewajiban suami istri dan suami istri tersebut agar bisa saling menerima kekurangan masing masing dan supaya mehilangkan sifat egois nya baik suami maupun istri agar perdamaian itu dapat tercipta tanpa menggunakan proses kekerasan sedikitpun.

KH. M Suadi Said sebagai Ulama Salaf Desa Won.Beliau mengatakan bahwa solusi yang tepat jika terjadi perselisihan dan permasalahan dalam kehidupan keluarga adalah suami sebagai kepala keluarga harus bisa menjadi suri tauladan yang baik bagi istrinya, karena segala perbuatan atau tindak laku suami akan ditirukan atau akan dicontoh oleh istri, untuk itu suami benar benar dituntut untuk bisa menjadi contoh yang baik bagi istrinya $^{52}$.

Ulama'Tafsir Modern Buya Hamka Dalam Tafsir Al Azhar juga mengatakan, Beri mereka petunuk dan

\footnotetext{
${ }^{51}$ Syaikh Imam Al-Qurtubi ,AlJami' li Ahkam Al Quran : "Tafsir Al Qurtubi", diterjemahkan oleh Akhmad Rijali Kadir , (Cet. I; Jakarta:Pustaka Azzam, 2008), 394 ${ }^{52}$ Khosim, Wawancara, Malang, Tanggal 10 September 2013.
} 
pengajaran, tunjuk ajarilah mereka dengan baik, sadarkan mereka akan kesalahannya. Suami yang baik akan dapat menetukan dan memilih kata-kata dan sikap yang layak untuk mengajari istri. Kadang-kadang ada istri yang tinggi hati, sombong karena hidupnya biasa senang dengan orang tuanya lalu dipadang enteng suaminya.Maka suami hendaklah mengajarinya dan menyadarkannya, bahwasaanya setelah bersuami, apapun yang diberikan suami kepada istrinya terimalah dengan baik. ${ }^{53}$

Karena apabila seseorang telah bersuami, apabila bercerai dengan suaminya, jika ia pulang kembali kepada tanggungan ibu bapak, tidak akan lagi seperti sewaktu ia masih gadis. Dan beberapa misal yang lain, yang suami memberikan pengajaran itu tidak boleh bosan, tetapi jangan nyinyir. Karena dalam mendirikan dan menegakkan ketrentraman dalam kehidupan berumah tangga kadang-kadang meminta waktu berpuluh tahun. Suami hendaknya menunjukkan pimpinan yang tegas dan bijaksana.

Kesimpulan pendapat dari $\mathrm{KH}$. M Suadi Said tentang cara penyelesaian perselisihan dalam kehidupan rumah tangga adalah, Suami agar memberikan pendidikan kepada istrinya tentang hak dan kewajiban suami istri dalam kehidupan rumah tangga, dan suami agar menjadi suri tauladan yang baik bagi istrinya dikarenakan suami merupakan kepala keluarga dan segala tindak laku suami secara tidak langsung akan dicontoh oleh sang istri.

\section{Ulama Modern}

KH. Abdul Wahabmengatakan bahwa solusi yang tepat ketika permaslahan dalam rumah tangga terjadi adalah: pihak suami istri agar mencari momen yang tepat dan indah untuk selanjutnya diajak bicara membahas apa yang sebenarnya terjadi dalam kehidupan rumah tangga tersebut

\footnotetext{
${ }^{53}$ Prof. Dr. Hamka , "Tafsir Al-Azhar juz 5" (Jakarta: P.T Metro Pos Jakarta, 1981). h.60
}

dengan mendatangkan juru damai dari kedua belah pihak, dengan ini suami istri saling intropeksi diri masing masing supaya saling menyadari semua kesalahannya masing masing, dan setelah menyadarinya maka perdamaian tersebut akan timbul.

Sayyid Qutb Dalam Kitab Tafsir Fi Zhilalil Quran Juga mengatakan Cara yang tepat untuk menyelesaikan permasalahan yang terjadi dalam kehidupan rumah tangga adalah dengan cara mendatangkan juru damai dari kedua belah pihak, cara ini harus dilakukan, keduanya bertemu dalam suasana yang tenang, jauh dari subjektivitas, jauh dari perasaan yang menyelimuti, jauh dari kondisi kehidupan yang menyelimuti kejernihan hubungan suami istri. Juga bebas dari segala pengaruh yang merusak suasana kehidupan, yang meruwetkan urusan, yang yang karena dekatnya hubungan jiwa suami istri semuanya itu tampak besar dan menutupi semua unsur kebaikan yang lain dalam kehidupan mereka.

Dengan penuh keinginan menjaga nama baik keluarga, dengan penuh kasih sayang terhadap anakanaknya yang kecil, dengan melepaskan segala keinginan mengalahkan dan menyalahkan sebagaimana yang sering terjadi antara kedua suami istri dalam kondisi seperti ini. Dan penuh keinginan dalam kebaikan suami istri dan anak-anaknya serta organisasi rumah tangganya yang terancam runtuh.

Kedua hakam berkumpul untuk mencoba melakukan islah (perbaikanperdamaian) Jika dalam hati suami istri itu masih ada keinginan yang sungguh untuk kebaikan, dan hanya kemarahan saja yang menghalangi keinginan itu, dan di tunjang kemauan yang kuat dari hati kedua hakam, maka Allah akan memberikan kebaikan dan Taufik kepada keduanya.

Kesimpulan pendapat dari $\mathrm{KH}$. Abdul Wahab dalam solusi untuk menyelesaikan perselisihan dalam rumah tangga adalah, pihak suami istri agar 
mencari momen yang tepat dan indah untuk selanjutnya diajak bicara membahas apa yang sebenarnya terjadi dalam kehidupan rumah tangga tersebut dengan mendatangkan juru damai dari kedua belah pihak, dengan ini suami istri saling intropeksi diri masing - masing supaya saling menyadari semua kesalahannya masing masing, dan setelah menyadarinya maka perdamaian tersebut akan timbul.Jika dalam hati suami istri itu masih ada keinginan yang sungguh untuk kebaikan, dan hanya kemarahan saja yang menghalangi keinginan itu, dan di tunjang kemauan yang kuat dari hati kedua hakam , maka Allah akan memberikan kebaikan dan Taufik kepada keduanya.

Ust. Munir Memaparkan pendapatnya tentang solusi yang tepat untuk menyelesaikan perselisihan dalam rumah tangga dengan cara, pihak suami istri saling membicarakan secara terang terangan apa sebenarnya yang sebenarnya terjadi, dikarenakan penyebab terjadinya perselisihan terebut bukan tidak munkin dari istri saja tapi bisa saja datang dari pihak suami. Dengan dilakukannya hal ini permasalahan tersebut akan terselesaiakan secara sendirinya dan jika ini selalu dilakukan, maka permaslahan serta perselisihan yang terjadi dalam keluarga tidak akan terjadi kembali.

Aminah Wadud juga mengatakan Soal pemulihan kehar-monisan perkawinan Al-Quran lebih mengutamakan kondisi yang harmonis dan menegaskan pentingnya memulihkannya. Dengan kata lain, bukan tindakan disipliner yang harus digunakan untuk mengatasi perselisihan diantara pasangan suami istri. Solusi yang terbaik yang ditawarkan Al-Quran dan lebih diutamakan oleh Al-Quran adalah dengan cara dengan cara musyawarah atau Syura, sebagai metode yang terbaik untuk memecahkan permaslahan diantara kedua belah pihak. ${ }^{54}$

\footnotetext{
${ }^{54}$ Aminah Wadud , "Quran Menurut Prempuan" (Jakarta : Serambi ilmu Semesta, 2001). h.129
}

Jelas bahwa Al-Quran bermaksud memecahkan permaslahan dan kembali pada kedamaian dan keharmonisan diantara kedua pasangan itu ketika Al-Quran menyatakan, tidak ada dosa bagi keduanya jika mereka mengadakan kedamaian yang sebenarnya. Perdamaian itu lebih baik, sesuai dengan Firman Allah SWT Pada Qs AnNisa ayat 128 yang artinya:

“ Dan jika seorang wanita khawatir akan nusyuz] atau sikap tidak acuh dari suaminya, Maka tidak mengapa bagi keduanya Mengadakan perdamaian yang sebenar-benarnya, dan perdamaian itu lebih baik (bagi mereka) walaupun manusia itu menurut tabiatnya kikir. dan jika kamu bergaul dengan isterimu secara baik dan memelihara dirimu (dari nusyuz dan sikap tak acuh), Maka Sesungguhnya Allah adalah Maha mengetahui apa yang kamu kerjakan"

Yang menjadi tujuan utama dalam penyelesaian perselisihan dan pertengkaran rumah tangga adalah perdamaian dan mengadakan perbaikan, bukan kekerasan dan kepatuhan yang dipaksakan.

Kesimpulan pendapat dari Ust Munir dalam solusi penyelesaian perselisihan dan permasalahan dalam keluarga adalah: pihak suami istri saling membicarakan secara terang terangan apa sebenarnya yang sebenarnya terjadi, dikarenakan penyebab terjadinya perselisihan terebut bukan tidak mungkin dari istri saja tapi bisa saja datang dari pihak suami. Dengan dilakukannya hal ini per-masalahan tersebut akan terselesaiakan secara sendirinya dan jika ini selalu dilakukan, maka permaslahan serta perselisihan yank terjadi dalam keluarga tidak akan terjadi kembali.

Ustdz. Siti Romlah dalam memapakarkan solusi untuk menyelesaikan permasalahan dan perse-lisihan dalam kehidupan rumah tangga adalah, Permaslahan yang timbul dan yang 
sudah tidah bisa diselesaikan atau sudah mencapai puncaknya hendaknya dimusyawarahkan dengan kepala yang benar benar dingin, dengan dibantu dengan mendatangkan juru damai dari kedua belah pihak. Agar supaya uneguneg yang ada dalam hati suami dan hati istri dapat tersampaikan dengan baik sehingga saling mengetahui keinginan masing masing, dengan ini secara langsung akan menyelesaikan permaslahan yang sedang terjadi dalam kehidupan rumah tangga.

Ahmad Mustahafa Al maraghi juga mengatakan dalam kitab Tafisr Almaraghi, beliau mngatakan bahwa, Khitha ini bersifat umum, termasuk didalamnya suami istri dan kaum kerabatnya, yang paling utama mengutus hakam adalah mereka.Jika tidak ada, maka kaum muslimin yang mendengar persoalan mereka hen-daknya berusaha memperbaiki hubungannya. Pertikaian diantara mereka kadang kadang disebabkan oleh nusyuznya istri, kadangkadang pula disebabkan oleh kezhaliman suami. Jika hal yang pertama yang terjadi hendaknya suami mengatasinya dengan cara paling ringan diantara cara-cara yang disebutkan dalam ayat-ayat terdahulu.

Tetapi jika hal yang kedua yang terjadi, dan dikhawatirkan suami akan terus menerus berlaku zhalim atau sulit menghilangkan nusyuzynya, selanjutnya dikhawatirkan akan terjadi perpecahan antara mereka tanpa menegakkan rukun rumah tangga yang tiga: ketenangan, kecintaan, dan kasih sayang, maka kedua suami istri dan kaum kerabat wajib mengutus dua orang hakam yang bermaksud untuk memperbaiki hubungan antara mereka. jika maksud dan tekad mereka benar, maka dengan karunia dan dan kemurahan Allah SWT akan mempersatukan kembali. ${ }^{55}$

\footnotetext{
${ }^{55}$ Ahmad Mustofa Al-Maraghi :"Tafsir Al-Maraghi”, diterjemahkan oleh, Bahrun Abu Bakar, Lc, Drs Hery Noer Aly (Cet. 1; Semarang: Cv.Toha Putra, 1986), h. 49
}

Kesimpulan dari pendapat Ustdz. Siti Romlah tentang solusi yang tepat untuk mengatasi permasalahan yang sedang terjadi dalam rumah tangga adalah :Permaslahan yang timbul dan yang sudah tidah bisa diselesaikan atau sudah mencapai puncaknya hendaknya dimusyawarahkan dengan kepala yang benar benar dingin, dengan dibantu dengan mendatangkan juru damai dari kedua belah pihak. Agar supaya uneg-uneg yang ada dalam hati suami dan hati istri dapat tersampaikan dengan baik sehingga saling mngetahui keinginan masing masing, dengan ini secara langsung akan menyelesaikan per-maslahan yang sedang terjadi dalam kehidupan rumah tangga.

\section{Ulama Kontemporer}

Sebagai Ulama Kontemporer dan sebagai tenaga pengajar di STIT Ibnu Sina Kepanjen KH. Zainul Arifin mengatakan pendapatnya dalam menyelesaikan permaslahan dalam kehidupan rumah tangga adalah : Menurut saya solusi yanng tepat untuk menyelesaikan perselisihan dan permasalahan dalam kehidupan rumah tangga adalah: Suami supaya memberikan pencerhan atau ilmu pengetahuan tentang hak dan kewajiban suami istri dan suami istri tersebut agar bisa saling menerima kekurangan masing masing dan supaya menghilangkan sifat egoisnya baik suami maupun istri agar perdamaian itu dapat tercipta tanpa menggunakan proses kekerasan sedikitpun.

Ulama Tafsir Modern Ahmad Musthafa Maraghi, juga mengatakan Hendaklah para suami memberikan nasehat yang menurut pandangan kalian dapat menyentuh hati mereka, sebab diantara kaum wanita ada yang cukup dengan diingatkan akan hukuman dan kemurkaan Allah. Di-antara mereka ada yang hatinya tersentuh oleh ancaman dan peringatan akan akibat yang buruk didunia, seperti ditahan untuk mendapatkan beberapa kesenangannya, seperti 
pakaian, perhiasan dan lain sebagainya. Sebagaimana sesuai dengan Firman Allah SWT Pada QS. At-Tahrim Ayat 6

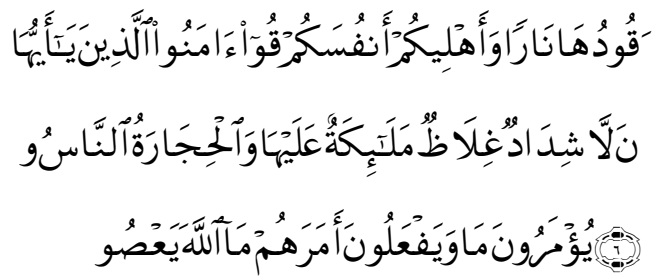

Artinya:

Hai orang-orang yang beriman, peliharalah dirimu dan keluargamu dari api neraka yang bahan bakarnya adalah manusia dan batu; penjaganya malaikatmalaikat yang kasar, keras, dan tidak mendurhakai Allah terhadap apa yang diperintahkan-Nya kepada mereka dan selalu mengerjakan apa yang diperintahkan.

Inilah tindakan yang harus dilakukan oleh suami kepada sang istri yaitu memberi nasehat kepadanya. Inilah tindakan yang harus dilakukan pemimpin dan kepala rumah tangga, yaitu melakukan tindakan pendidikan, yang memang senantiasa dituntut kepadanya dalam semua hal.

Nasehat tersebut juga harus mengandung dorongan untuk mendapatkan pahala menjadi wanita solehah yang senantiasa menjaga dirinya, sekaligus mengandung ancaman akan balasan yang akan menimpa wanita yang membangkang dan durhaka.

Kesimpulan Dari Pendapat KH. Zainul Arifin tentang solusi penylesaian dalam rumah tangga adalah; Suami supaya memberikan pencerhan atau ilmu pengetahuan tentang hak dan kewajiban suami istri dan suami istri tersebut agar bisa saling menerima kekurangan masing masing dan supaya mehilangkan sifat egois nya baik suami maupun istri agar perdamaian itu dapat tercipta tanpa menggunakan proses kekerasan sedikitpun.

Ust Arbain Nurdin memaparkan dalam pendapatnya tentang solusi dalam menyelesaikan permasalahan dalam rumah tangga yaitu dengan cara
:Mendatangkan Juru damai dari kedua belah pihak, pihak suami dan istri, agar ihak suami istri tersebut bisa saling menerima kekurangan dan kelebihan dari pasangannya, dikarenakan jika saling menerima dan saling mngertia antara suami dan istri permaslahan yang terjadi akan luluh dan akan segera teselesaiakan dengan sendirinya, karena pemicu terjadinya permasalahan tersebut adalah pasangan suami istri itu sendiri.

Buya Hamka juga memaparkan dalam Kitab Tafsirnya, Tafsir Al-Azhar Maka utuslah seorang hakam dari ahli si laki-laki dan seorang hakam dari si ahli perempuan, Hakam yang pokok adalah artinya sama dengan hakim. Hakam ialah penyelidik duduk perkara yang sebenarnya, sehingga mereka dapat mengambil kesimpulan.Kedua hakam tersebut diutus oleh kedua masyarakat kaum muslimin, atau keluarga terdekat kedua belah pihak.Hakam si laki-laki, menyelidiki pendirian si laki-laki, denan seksama, sedangkan hakam si perempuan menyelidiki pendirian si perempuan dengan sek-sama pula. Setelah lengkap di-ketahui, mereka bertemu kembali, lalu soal itu dikaji dengan kepala dingin. ${ }^{56}$

Kesimpulan pendapat dari Ust. Arbain Nurdin adalah: Agar Pihak suami dan istri yang sedang berselisih mendatangkan Juru damai dari kedua belah pihak, pihak suami dan istri, agar suami istri tersebut bisa saling menerima kekurangan dan kelebihan dari pasangannya, dikarenakan jika saling menerima dan saling mngertia antara suami dan istri permaslahan yang terjadi akan luluh dan akan segera terselesaiakan dengan sendirinya, karena pemicu terjadinya permasalahan tersebut adalah pasangan suami istri itu sendiri.Dan agar pihak suami istri tersebut benar-benar menyerahkan kepada hakam dengan sepenuhnya.

\footnotetext{
${ }^{56}$ Prof. Dr. Hamka , "Tafsir Al-Azhar juz 5" (Jakarta: P.T Metro Pos Jakarta, 1981). h. 67
} 
Ustdz.Ustz. Esti Luluin, memberikan pendapat tentang solusi penyelesaian yang harus dilakukan ketika perselisihan dalam rumah tangga terjadi adalah: Agar Mendatangkan Juru damai dari kedua belah pihak yang bisa dipercayai, dan nantinya pihak suami maupun istri supaya saling intropeksi dirinya masing-masing, dan tidak hanya bisa saling menyalahkan antara satu dengan yang lainnya, dikarenakan permasalahan yang sedang mendera dalam keluarga tersebut adalah pa-sangan suami istri itu sendiri.

Imam Al-Qurtubi Juga mengatakan ketika perselisihan diantara keduanya semakin ruwet maka dianjurkan mengutus mediator dari kedua belah pihak, menunjukkan bahwa hukum yang berlaku pada keduanya (juru damai) bukan yang berlaku pada suami istri, oleh karena itu dianjurkan kepada kedua belah pihak mengutus mediator dari pihak keluarganya masing-masing. Dan kedua mediator itu haruslah orang yang dipercaya oleh mereka berdua dan mewakili kedua belah pihak tentunya juga disertai dengan ridha kedua suami istri untuk berembuk agar mereka berdua rujuk atau bercerai jika mereka melihat hal itu yang paling terbaik.Hal ini menunjukkan bahwa kedua mediator itu berkedudukan sebagai wakil dari kedua suami istri. ${ }^{57}$

Dua juru damai itu mesti dari keluarga suami dan istri, karena keduanya lebih memahami keadaan mereka, dan keduanya termasuk orang yang adil, mempunyai pandangan yang bagus dan memahami Fiqh. Jika tidak ada dari pihak keluarganya yang layak untuk itu, maka kirimlah orang yang adil dan mengerti.

Keputusan Hukum dari kedua Hakam suadah barang tentu tidak selalu akan disukai saja oleh orang yang diberi

\footnotetext{
${ }^{57}$ Syaikh Imam Al-Qurtubi, :"Tafsir Al-Qurtubi”, diterjemahkan oleh, Ahmad Rijali Kadir (Cet. 1; Jakarta: Pustaka Azam , 2008), h. 408
}

hukum. Untuk menghilangkan keraguan Imam As-Syafi'I dan Imam Abu Hanifah memberikan syarat supaya kedua suami istri yang berselisih itu benarbenar menyerahkan kekuasaan mengambil apa saja keputusan kepada kedua hakam itu, dan mereka akan taat menerimanya. Sebab Sayyidina Ali belum mau melepaskan laki laki yang tidak mau menyerah kalau mau diceraikan itu, sebelum dia menyerah-kan keputusan kepada hakam se-penuhnya.

Kesimpulan pendapat Dari Ustdz.Ustz. Esti Luluin adalah: agar Mendatangkan Juru damai dari kedua belah pihak yang bisa dipercayai, dan nantinya pihak suami maupun istri supaya saling intropeksi dirinya masing-masing, dan tidak hanya bisa saling menyalahkan antara satu dengan yang lainnya, dikarenakan permasalahan yang sedang mendera dalam keluarga tersebut adalah pasangan suami istri itu sendiri. Dan agar benar benarbenar menyerahkan semua ke-putusan kepada pihak juru damai dengan sepenuhnya.

\section{KESIMPULAN DAN SARAN}

\section{Kesimpulan}

Makna Lafadz Idrib Menurut Ulama Kabupaten Malang sebagai berikut:

$$
\text { Ulama Kabupaten Malang }
$$

dalam memaknai Lafadz Idrib ini dibedakan ke dalam dua kategori, Kategori yang pertama yaitu kategori ulama Salaf, Para Ulama salafi memaknai lafadz Idrib ini dengan me-mukul secara tekstual yaitu memukul dengan tangan, dengan syarat tahapan-tahapan sebelumnya telah dilakukan dengan baik, dan dalam melakukan pemukulan tersebut terdapat batasan-batasan tertentu supaya tidak membahayakan istri setelah dilakukannya proses pemukulan tersebut. Kategori yang kedua yaitu ulama Modern dan Kontemporer, Dalam memaknai La-fadz Idrib pada Qs An-Nisa Ayat 34 para ulama Modern dan kontemporer memaknainya dengan pukulan secara kontekstual, yaitu cukup hanya memu-kulnya dengan kata-kata atau nasehat, karena menurut para ulama Modern 
dan Kontemporer permasalahan akan menjadi semakin runyam jika dalam proses penyelesaiannya menggunakan jalan kekerasan.

Solusi jika terjadi perselisihan antara suami istri perspektif ulama Kabupaten Malang terdapat Dua kategori, Yaitu Penyelesaiannya Menurut Ulama Salafi adalah boleh melakukan pemuklan terhadap istri yang durhaka, dikarnakan proses-proses sebelum dilakukannya pemkulan sudah dilaksanakan dengan baik dan istri masih dalam tanggung jawab si suami. Sedangkan untuk kategori yang kedua yaitu ulama Modern dan Kontemporer. Menurut Mereka solusi yang tepat dalam menyelesaikan perselisihan yang terjadi dalam kehidupan rumah tangga adalah tanpa menggunakan cara kekerasan sedikitpun, dikarenakan jika menggunakan jalan kekerasan, istri tidak akan menjadi baik dan istri akan mengambil sikap berontak atas dilakukannya proses penyelesaian dengan cara kekerasan tersebut.

A. Saran

Sebagai pentup dari pembahasan ini, peneliti mengemukakan dan merekomendasikan saran, sehingga dapat memberikan manfaat khususnya bagi:

Diharapkan sebelum melakukan pernikahan pihak laki-laki dan perempuan dalam memilih jodoh tidak asal-asalan atau hanya faktor cinta, tetapi harus di tentukan secara matang matang dan dipertimbangkan secara matang-matang bagai-mana sifat atau karakter calon pasangan yang akan dinikahi nantinya, dengan dilakukannya proses ini secara otomatis perselisihan yang terjadi dalam rumah tangga dapat diminimalisir sekecil mungkin.

Bagi suami sebagai rumah tangga untuk menjadi tauladan yang baik dalam keluarganya terutama contoh bagi sang istri, dikarenakan sedikit banyak perilaku suami akan dicontoh oleh sang istri.

\section{DAFTAR PUSTAKA}

A. BUKU-BUKU

Adhim, M. Fauzil. Kupinang Engkau

Dengan Hamdalah, Yogyakarta: Mitra

Pustaka, 1999, 129.

Al-Mashiri,Syaikh Mahmud" Perkawinan Idaman", diterjemahkan Iman Firdaus Lc, Q, Dpl Cet.I ; Jakarta: Qisthi Press, 2011

Al Qurtubi,Syaikh Imam Al Jami' li Ahkaam Al Qur'an: "Tafsir AlQurtubi", diterjemahkan oleh Ahmad Rijali Kadir, (Cet. I; Jakarta:Pustaka Azzam, 2008

Tihami, Syahrani Sohari, Fikih Munakahat ,Jakarta; Rajawali Press, 2009.

AlHamidMuhammad Bin Ibrahim, " Min Akhta' Az-Zaujat", diterjemahkan olehMuhammad Muhtadi Lc, DosaDosa Suami Istri Yang meresahkan Hati, Cet I ; Solo: Kiswah, 2011.

Utsman al-KhusyMuhammad ,Membangun Harmonisme Keluarga , (Jakarta; Qisthi Press, 2007.

Sayyid SalimAbu Malik, Kamal bin As, “ Shahih Fiqh As-sunnah Wa Adillatuhu wa Tau", diterjemahkan oleh Iman Fhih Madzahib Al

Aimmah,diteterjemahkan oleh Khairul Amru Harahap, Faisal Saleh, Perkawinan Idaman, Cet I ; Jakarta: Pustaka Azam, 2007.

Sabiq,Sayyid. "Fiqhus Sunnah ”, diterjemahkan oleh Nor Hasanudin Lc, Fikiqih Sunnah, Cet I ; Jakarta: Pena Pundi Aksara Press, 2006.

Fauzan Zenrif, Muhammad. Sintesis Paradigma Studi Al- Quran ,Malang; UIN Malang Press, 2008.

Hamka , "Tafsir Al-Azhar juz 5" Jakarta: P.T Metro Pos Jakarta, 1981.

Syaikh Mahmud Al-Masri, “ Az-zawaj alislami as-Sai' d", diterjemahkan oleh Iman Firdaus, Perkawinan Idaman, Cet I ; Jakarta: QISTHI PRESS, 2011. 
Abdullah bin Muhammad Bin

Abdurahman bin Ishaq Alu Syaikh., “

Lubabut Tafsiir Min Ibni Katsiir", diterjemahkan oleh M.Abdul Ghoffar

E.M, Tafsir Ibnu Katsir jilid 2Cet IV ;

Jakarta: Pustaka Imam ASY-

SYAFI'I,2006.

Anwar, Rosihan. Samudera al-Qur'an,

Bandung: Pustaka Setia, 2001.

Al Fatih Suryadilaga,Muhammad. dkk, Metodologi Ilmu Tafsir , Sleman; TERAS, 2005.

Quthb Sayyid, Tafsir Fizhilalil Qura'an :

"Tafsir di Bawah Naungan Qura'an", diterjemahkan oleh, As'ad Yasin, Abdul Aziz Salam Basyarahil., Muchotob Hamzah, Cet. 4; Jakarta:Pustaka Gema Insani, 2008.

Al-Maraghi, Ahmad Mustofa : "Tafsir AlMaraghi", diterjemahkan oleh, Bahrun Abu Bakar, Lc, Drs Hery Noer Aly, Cet. 1; Semarang: Cv.Toha Putra, 1986.

Mustaqim, Abdul. "Epistimologi Tafsir Kontemporer" Yogyakarta: LKis, 2010.

Quraish Shihab, Muhammad "Tafsir Al Misbah", Lentera Hati.

Sukmadinata, Nana Syaodih. Metode Penelitian Pendidikan, Bandung: PT Remaja Rosdakarya, 2005.

Sugiyono, Metode Penelitian Kuantitatif, Kualitatif R\&D. Bandung: Peneribit Alfabeta, 2010.

Soekanto, Soerjono, Pengantar Penelitian Hukum, Jakarta: UI-Press, 2006.

Amiruddin, SH,.M.Hum. H. Zainal Asikin, S.H, Pengantar Metode Penelitian Hukum, Jakarta; Raja

GrafindoPersada.

Sukmadinata, Nana Syaodih. Metode Penelitian Pendidikan, Bandung; Rosda, 2005.

J. Moleong, Lexy. "Metodologi Penelitian Kualitatif' Bandung: PT Remaja Rosda Karya, 2002.

Azwar,Saifuddin. Metode Penelitian Yogyakarta: Pustaka Pelajar, 1998.

Tim Dosen Fakultas Syari'ah UIN Malang, Pedoman Penulisan Karya Ilmiah, Malang: 2011.
Arikunto,Suharsimi. prosedur penelitian: Suatu Pendekatan Praktek.( Jakarta: PT Rineka Cipta, 2006) h. 227.

Bambang Sunggono, Motode Penelitian Hukum, Jakarta: Raja Grafindo Persada, 2003.

Nazir, Mohammad. Metode Penelitian, Jakarta: Ghalia Indonesia, 2009

Nana Sudjana dan Ahwal Kusuma, Proposal Penelitian: Di Perguruan Tinggi, Bandung: Sinar Baru Aldasindo, 2000.

Muhammad bin Jarir Ath-Thabari, Abu Ja'far. Jami' Al Bayan an Ta'wil Ayi Al Quran: "Tafsir Ath-Thabari", diterjemahkan oleh Akhmad Afandi, Cet. I; Jakarta:Pustaka Azzam, 2008.

Wadud, Aminah. "Quran Menurut Prempuan "Jakarta : Serambi ilmu Semesta, 2001.

B. SKRIPSI

Qonita, Shofa. "Perlindungan Terhadap Istri Sebagai Korban Kekerasan Dalam Rumah Tangga Perspektif Hukum Islam Dan UU No 23 Tahun 2004.", Skripsi Uin Malang Tahun 2005

Hidayatin, Nora. "Respon Mahasiswa Fakultas Syari'ah UIN Malang Terhadap Kekerasan DalamRumah Tangga Perspektif Gender", Skripsi UIN Malang, Tahun 2005.

\section{Azizah, "Pemahaman Isteri Korban Kekerasan Dalam Rumah Tangga Yang Dilakukan Suami” Skripsi UIN Malang, Tahun 2007.}

C. WAWANCARA

Mukhlis Yahya, Wawancara, Malang,

Tanggal 27 Februari 2014

Zainul Fanani, Wawancara, Malang,

Tanggal 27 Februari 2014

M Suadi Said, Wawancara, Malang, Tanggal 27 Februari 2014.

Abdul Wahab , Wawancara, Malang, Tanggal 28 Februari 2014. 
164 | M. Lukman Haris, Makna Lafadz QS. An Nisa

Munir, Wawancara, Malang, Tanggal 28 Februari 2014.

Siti Romlah , Wawancara, Malang, 28 Februari 2014.

Zainul Arifin , Wawancara, Malang, Tanggal 1 Maret 2014

Arbain ,Wawancara, Malang, Tanggal 1 Maret 2014

Esti Luluin, Wawancara, Malang, Tanggal 1 Maret 2014 